\title{
Detection Of Water Levels In Sewering Channels As Flood Disaster Early Warning System
}

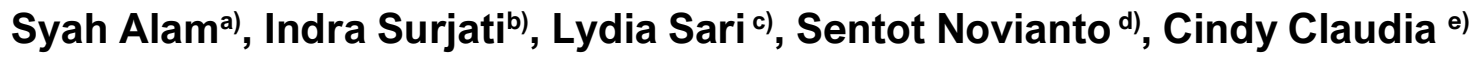 \\ Tambunan, Akmal Mahendra f), Tri Swasono Ad g) \\ a,b,c,ef,g) Jurusan Teknik Elektro, Universitas Trisakti, DKI Jakarta, Indonesia \\ d) Jurusan Teknik Mesin, Universitas Trisakti, DKI Jakarta, Indonesia \\ a)Corresponding Author: syah.alam@trisakti.ac.id
}

\begin{abstract}
In 2020 a number of areas in DKI Jakarta were hit by floods, one of which was the North Tanjung Duren Village, Grogol Petamburan District, West Jakarta. The extreme rainfall of $377 \mathrm{~mm} /$ day has flooded almost all areas of DKI Jakarta and its surroundings. In addition, poor drainage causes water to stagnate, causing flooding. However, the absence of an early flood information system makes residents restless when the rainy season arrives. The Community Service (Community service activity) activity carried out aims to provide training to the community in the Tanjung Duren Utara Village area RW 04, RT 0010 regarding water level detection equipment placed in culverts. This tool serves to provide early information if the volume of water in the culvert is full of information in the form of a siren sound. The method used in this Community service activity activity is to provide online counseling and training to the community in RT 0010 / RW 04, North Tanjung Duren Village, Grogol Petamburan District, West Jakarta. The results obtained are an increase in public understanding regarding the dangers of flooding to household electricity, as indicated by the results of the pre-test and post-test which are obtained an average of 43 and 90 , respectively. Public understanding of the dangers of flooding to electricity has increased up to $109.3 \%$. In addition, the average partner satisfaction with the material presented is $92 \%$, this shows that the material presented by the presenters team is very useful for the extension participants.
\end{abstract}

Key words: flooding, water level detection, community service, Tanjung Duren, culverts

\section{INTRODUCTION}

Tanjung Duren is a residential area in the Grogol Petamburan sub-district, West Jakarta. Tanjung Duren is divided into two regions, namely Tanjung Duren Utara and Tanjung Duren Selatan. Based on data obtained from the administrative city of West Jakarta, the area of North Tanjung Duren is $135.52 \mathrm{Ha}$ and southern Tanjung Duren is $136.63 \mathrm{Ha}$. In addition, based on (Jakarta, 2020) and Permendagri Number 137 of 2017 dated December 29, 2017, the Grogol Petamburan sub-district has 7 sub-districts namely Tanjung Duren Utara, Tanjung Duren Selatan, Tomang Grogol Selatan, Jelambar, Wijaya Kusuma, Jelambar Baru, Grogol Petamburan. Rain that occurred in Jakarta and its surroundings in early 2020 caused floods and landslides to hit a number of Jabodetabek areas. There are 5 municipalities in DKI Jakarta submerged with varying water levels, including South Jakarta, North Jakarta, West Jakarta, East Jakarta, Central Jakarta. The flood map published by BPBD DKI Jakarta (Central Bureau of Statistics, 2018).

The West Jakarta area is still included in the flood-affected area in February 2020, with a height of $10-30 \mathrm{~cm}$. Based on information obtained from (Suara.com, 2020) the Secretary River embankment in the Tanjung Duren area, West Jakarta was reported to have leaked, thus inundating the area due to high rainfall from Friday (17/1) night to Saturday (18/1) early morning. The cause of major flooding in early 2020 for the Jabodetabek area was extreme rainfall of $377 \mathrm{~mm} /$ day based on BMKG observations in the Halim Perdana Kusumah area, East Jakarta (Dahlia \& Fadiarman, 2020). The rain that occurred in Jakarta and its surroundings caused floods and landslides to hit a number of Jabodetabek areas (Harsoyo, 2013). In addition, clogged drainage also causes a buildup of water that causes flooding. The effects of the flood disaster that hit the community caused electrical short circuits in households due to electrical installations and electronic equipment that were submerged in water. This is very dangerous 
because it will pose a fire hazard and also the risk of being electrocuted by electric current from equipment submerged in flood water. For that we need an outreach to the community to be able to anticipate the dangers of flooding, especially in areas prone to flooding and densely populated areas. The Tanjung Duren area was chosen because the location is about $1.9 \mathrm{~km}$ from Trisakti University campus A, which is located on Jalan Kyai Tapa No. 1, West Jakarta. In addition, the Tanjung Duren area is an area that is prone to flood disasters, according to data released by the BMKG in early 2020 (Dahlia \& Fadiarman, 2020).

The problem from partners is that there is no flood early warning tool in the Tanjung Duren Utara Village area, especially RT 0010 / RW 04 so that people do not know that there are puddles on the road due to full water in the culverts. This needs to be known by the public as a preventive effort and early information related to flood disasters. The purpose of the activities carried out is to provide an understanding to the community regarding the early detection of flood disasters by using the tools proposed for the community, especially in flood-prone areas. In addition, this activity aims to apply the field of electrical science, especially in the field of household electricity.

\section{METHOD}

The initial step in this community service activity is to carry out and build communication with the local area administrator, namely the chairman of RT 0010 / RW 04, North Tanjung Duren Village, Grogol Petamburan District. The discussion was carried out directly because one of the proposing members in this community service activity is a resident who lives in the local area so it is easier to dig up information related to community needs. Furthermore, the topic and direction of the activities to be carried out are conveyed verbally to the local regional administrator for technical discussion and the date of implementation. Furthermore, the team prepared educational materials and suggestions for Community service activity activity participants in the form of E-Posters and also materials in the form of power points. Furthermore, the community service activity team conducted a survey to the location of the activity and carried out the design and placement of a water level detection device. After that, the community service activity implementation team prepared training materials and facilities for community service activity participants in the form of modules and posters on the use of water level detectors. In addition, the community service activity implementation team also provides online meeting room facilities via Google Meet to discuss and carry out counseling activities. The counseling activity was carried out on Sunday, July 18, 2021 and was attended by 10 participants.

The implementation process is carried out using an online method, Community service activity participants will be given a link to access the online discussion room Via Google Meet. The material that will be given has been prepared in the form of modules and power points will be asked to fill out a questionnaire related to understanding the early detection system for flood disasters using Google Forms. Furthermore, after the Community service activity team provided material according to the topic, Community service activity participants were given the opportunity to ask questions and discuss with the presenters and then filled out the same questionnaire that was given at the beginning of the Community service activity activity. This was done to measure the absorption rate of the material provided by the Community service activity presentation team. In addition, Community service activity partners will also be asked to fill out a partner satisfaction form as a measure of success and satisfaction with the activities that have been carried out.

The material that will be given is the working principle of the water level detector, installation and installation techniques and also its maintenance. Before conducting community service activity, the participants will be asked to fill out a questionnaire related to understanding the dangers of flooding in household electricity using Google Forms. Furthermore, after the community service activity team provided material according to the topic, all participants were given the opportunity to ask questions and discuss with the presenters and then filled out the 
same questionnaire that was given at the beginning of the activity. This was done to measure the absorption rate of the material provided by the community service activity presentation team. In addition, community service activity partners will also be asked to fill out a partner satisfaction form as a measure of success and satisfaction with the activities that have been carried out.

\section{RESULTS}

This community service activity was held on Sunday, July 182021 at 10.00 using an online meeting room via Google Meet. The community service activity implementation team who attended presented material related to the working principles and stages in designing and operating water level detection measuring instruments. The activity was carried out starting with conducting a pre-test on the activity participants to measure their initial understanding of the material presented. Furthermore, the implementation team explained the material related to the working principles of the tools proposed in PkM activities. Furthermore, participants were given the opportunity to ask questions with the presenters team. To measure the level of understanding of the participants, a post-test related to the material presented was conducted. The final stage of this community service activity is to measure the satisfaction of the material that has been delivered by the team of presenters. In addition, the presenters team also delivered material related to the design and implementation of the proposed water level detection device. The tool has been installed and works well to detect water levels in culverts in the Tanjung Duren area. The working principle of the designed tool is to detect the water level based on three indicators indicated by the LED lights mounted on the body of the detector. If the light is green, it means that the water level is normal with a limit of $10-15 \mathrm{~cm}$ from the bottom surface of the culvert, then the light will turn yellow if the water level has reached $30 \mathrm{~cm}$ from the bottom of the culvert surface, which means the water is almost full. The height of the culvert in RT 010/RW 04 Kelurahan Tanjung Duren Utara is $48 \mathrm{~cm}$, this is obtained from direct measurements in the field. For the last condition, when the red light is on, it means that the water has filled the culvert which is about $45 \mathrm{~cm}$ and the control circuit will sound the siren as a sign that the water is almost overflowing. The control circuit used is a relay connected to each buoy which functions as a switch to turn on the lights and sirens. The result of this activity is to gain public understanding regarding early detection of flood disasters using the proposed tool. After conducting PKM activities, the next step is to evaluate the achievement of the material given to participants using pre-test and post-test. The pre-test and post-test contained 10 questions related to the basic understanding of participants in the flood disaster early detection system. The number of correspondents in this activity is 10 people. From the activity process, it can be seen that when the pre-test was given the highest score from the participants was 60 (6 questions answered correctly), while the average pre-test score was 43 . After being given the material, participants took the post-test with the same instrument and the results became better. good with the highest score is 100 and the average score is 90 . This result shows that the material presented by the presenters team can be understood and accepted well by the community service activity participants.

Furthermore, in this community service activity, partner satisfaction was measured using a questionnaire with a linkert scale. From the activities carried out, it shows that the average partner satisfaction with the materials and training provided is $92 \%$, this shows that the material presented by the presenters team is very useful for the extension participants. Furthermore, the participants suggested that in the future, workshops should be given to the design of a water flow velocity detection device for culverts. The supporting factor of this activity is the establishment of good communication between activity implementers and partners so that activities can run smoothly. In addition, support from the Department of Electrical Engineering and Mechanical Engineering in terms of human resources (lecturers and students) also helps the implementation of this community service activity. The obstacles that hinder this community service activity are the internet network connection of the activity participants who are prone to 
interference due to the weather at the time of implementation in rainy conditions and also the implementation is carried out online due to the COVID-19 pandemic conditions.

\section{DISCUSSION}

Several community service activities have been carried out by previous researchers, namely sanitation education activities for flood-prone areas (Jumadewi \& Kurnaidi, 2021) then the activities proposed by (Rahmayanti et al., 2021) provide counseling on flood disaster mitigation skills for residents affected by floods. Community service activities that have been carried out previously are only limited to providing education and mitigation skills during flood disasters but have not proposed early detection of flood disasters. Several studies have proposed an early detection tool for flood disasters using a microcontroller approach (Umari et al., 2017) (Arifin et al., 2020) or loT (Internet of Things) proposed by (Hanggara et al., 2021) (Muzakky et al., 2021). ., 2018) but the obstacle is the level of complexity of the proposed tool so that people cannot assemble it independently and also the influence of signal quality during the rainy season is also an obstacle for the Internet Of Things system so that it is vulnerable to interference when providing information. This activity offers training for early detection tools that are easy to assemble, maintain and use by the community using appropriate technology that is more practical. In addition, the early information provided is also in the early information provided is also in the form of a siren sound that is easily understood by the public.

\section{CONCLUSIONS AND RECOMMENDATIONS}

This paper describes and explains community service activities related to early detection of flood disasters using tools that have been designed and designed previously. From the results of this activity, there was an increase in public understanding regarding the dangers of flooding in household electricity and corrosion of electronic equipment. From the results of the pre-test and post-test, an average of 43 and 90 were obtained, respectively. Public understanding of the dangers of flooding for early detection of flood disasters increased up to $109.3 \%$. Furthermore, the average partner satisfaction is $92 \%$, this shows that the material presented by the presenters team is very useful for extension participants. The suggestion from this activity is that it is necessary to hold a follow-up activity that provides material in the form of training in designing tools to detect the speed of water as a complement to a water level detector in culverts which functions to detect smoothness and blockage of water in culverts.

\section{ACKNOWLEDGMENTS}

This Community Service Activity is fully funded by the Community Service Institute of Universitas Trisakti through an internal grant for the 2020/2021 fiscal year with contract number 0329H/PR.05.00/FTI-DEK/XII/2020.

\section{REFERENCES}

Arifin, M. Z., Utami, E., \& Pramono, E. (2020). Perancangan Sistem Deteksi Dini Bencana Banjir Menggunakan Teknik Pengiriman DTMF Berbasis Modul RF 433 Mhz Dan Arduino. Jurnal Teknologi Informasi Dan Komunikasi (TIKomSiN), 8(2), 1-5. https://doi.org/10.30646/tikomsin.v8i2.465

Badan Pusat Statistik. (2018). Kecamatan Grogol Petamburan Dalam Angka 2018. Badan Pusat Statistik Kota Administrasi Jakarta Barat. www.bps.go.id

Dahlia, S., \& Fadiarman. (2020). Analisis Risiko Banjir Terhadap Fasilitas Pendidikan Di Dki Jakarta. Jurnal Geografi Gea, 20(2), 185-196.

Hanggara, D., Dani, R., \& Putra, E. (2021). Purwarupa Perangkat Deteksi Dini Banjir Berbasis Internet of Things. JIRE (Jurnal Informatika \& Rekayasa Elektronika), 4(1), 87-94.

Harsoyo, B. (2013). Mengulas Penyebab Banjir Di Wilayah Dki Jakarta Dari Sudut Pandang Geologi, Geomorfologi Dan Morfometri Sungai. Jurnal Sains \& Teknologi Modifikasi Cuaca, 14(1), 37. https://doi.org/10.29122/jstmc.v14i1.2680 
Jakarta, B. D. (2020). GIS DKI Jakarta. http://gis.bpbd.jakarta.go.id/documents/627

Jumadewi, A., \& Kurnaidi, H. (2021). Edukasi Sanitasi Air Bersih di Lingkungan Perumahan Daerah Rawan Banjir. 3(1), 15-21.

Muzakky, A., Nurhadi, A., Nurdiansyah, A., \& Wicaksana, G. (2018). Perancangan Sistem Deteksi Banjir Berbasis loT. Conference on Innovation and Application of Science and Technology (CIASTECH 2018), September, 660-667.

Rahmayanti, H., Azwar, S. A., Ichsan, I. Z., Ilyasa, F., \& Nasrun, A. (2021). Pemberdayaan Keterampilan Mitigasi Banjir Masyarakat Jakarta Melalui Penyuluhan (Kegiatan Pengabdian Saat Pandemik Covid-19). ETHOS: Jurnal Penelitian Dan Pengabdian Kepada Masyarakat, 9(1), 72-78. https://doi.org/10.29313/ethos.v9i1.6463

Suara.com. (2020). Kali Sekertaris Jebol. https://www.suara.com/news/2020/01/18/132039/jakarta-banjir-lagi-tanggul-kali-sekretarisdi-tanjung-duren-bocor

Umari, C., Anggraini, E., \& Zainul Muttaqinm Rofif. (2017). Rancang Bangun Sistem Peringatan Dini Banjir Berbasis Sensor Ultrasonik Dan Mikrokontroler Sebagai Upaya Penanggulangan Banjir. Jurnal Meteorologi Klimatologi Dan Geofisika, 4(2), 35-42. 


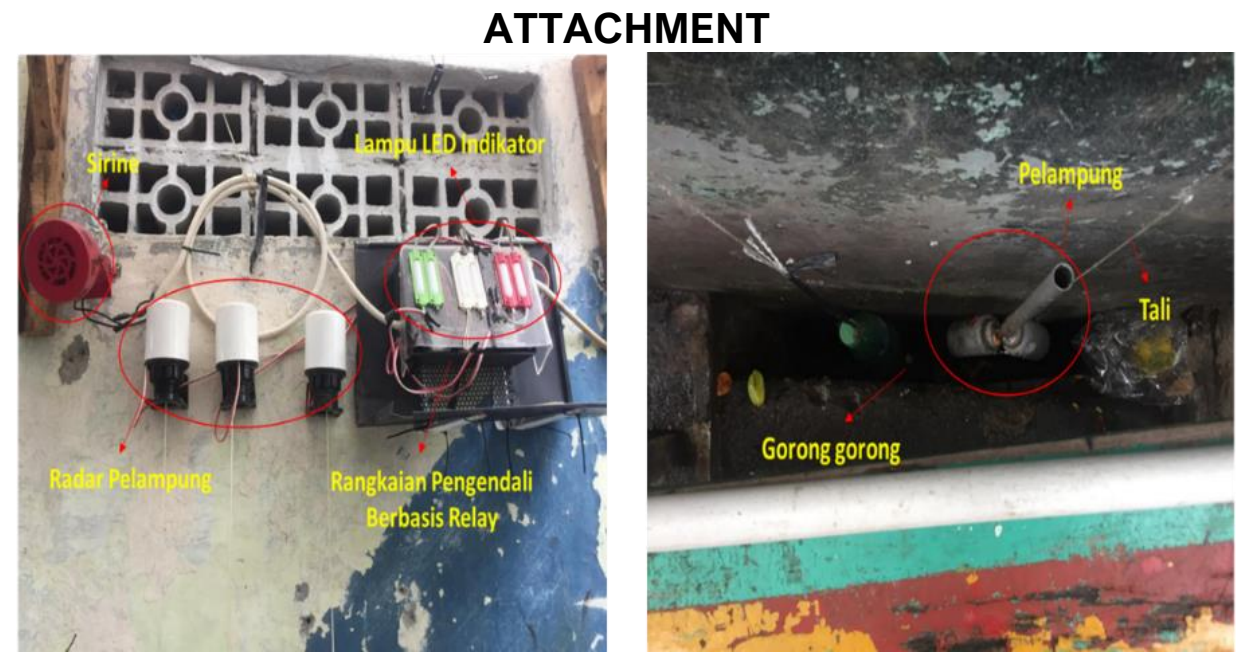

Figure 1. Implementation of Water Level Detection Tool

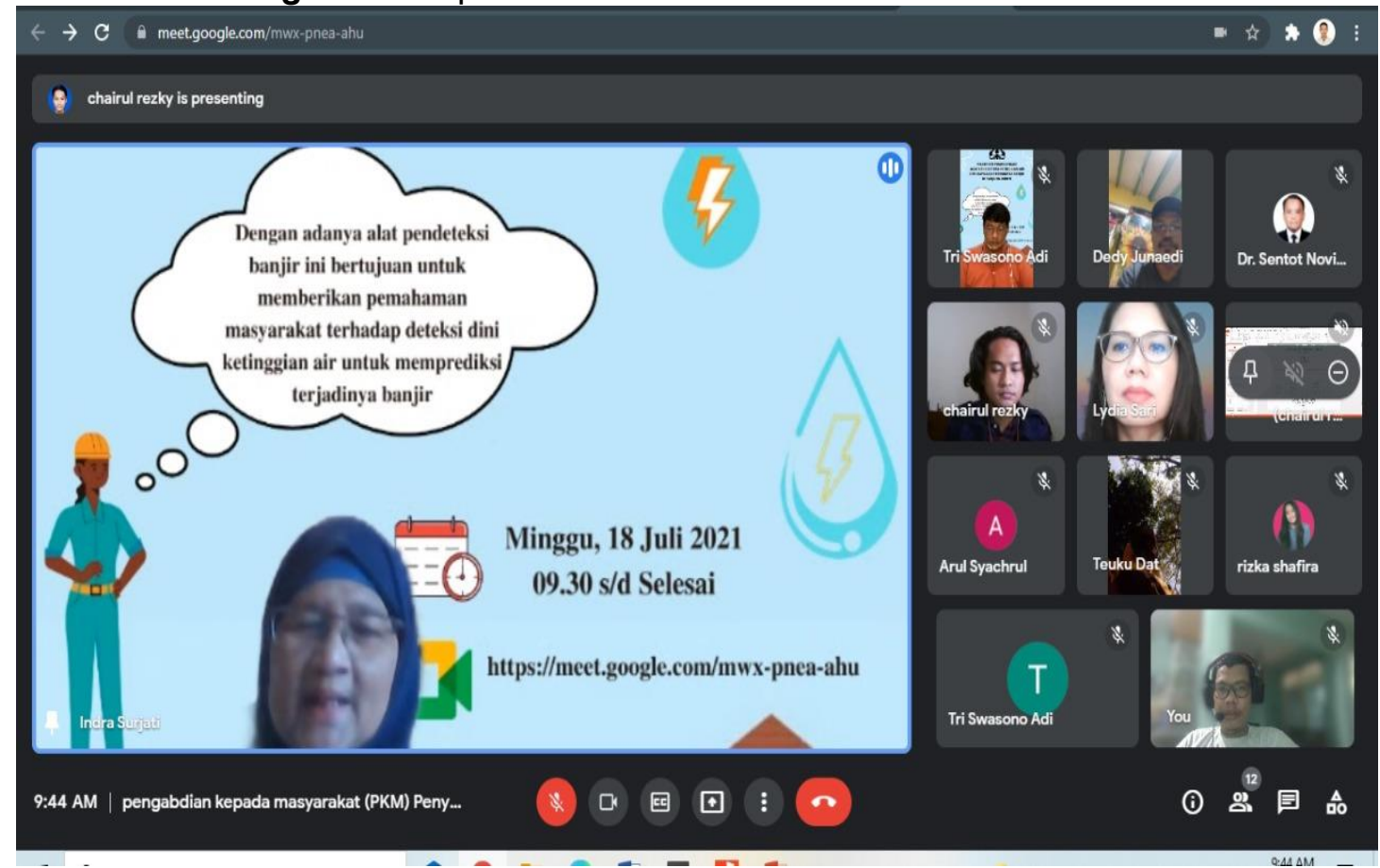

Figure 2. Implementation of community service activities 